Check for updates

Cite this: Chem. Sci., 2019, 10, 1212

¿ All publication charges for this article have been paid for by the Royal Society of Chemistry

Received 13th September 2018 Accepted 10th November 2018

DOI: $10.1039 / \mathrm{c} 8 \mathrm{sc} 04078 \mathrm{~h}$

rsc.li/chemical-science

\section{Reduction of organic azides by indyl-anions. Isolation and reactivity studies of indium-nitrogen multiple bonds $\uparrow$}

\begin{abstract}
Mathew D. Anker, (D) Matthias Lein (D) and Martyn P. Coles (D)*
The synthesis of a new potassium-indyl complex, $\mathrm{K}\left[\ln \left(\mathrm{NON}^{\mathrm{Ar}}\right)\right]\left(\mathrm{NON}^{\mathrm{Ar}}=\left[\mathrm{O}\left(\mathrm{SiMe} \mathrm{N}_{2} \mathrm{Nr}\right)_{2}\right]^{2-}, \mathrm{Ar}=\right.$ 2,6- ${ }^{i} \mathrm{Pr}_{2} \mathrm{C}_{6} \mathrm{H}_{3}$ ) and its reactivity with organic azides $\mathrm{RN}_{3}$ is reported. When $\mathrm{R}=2,6$-bis(diphenylmethyl)$4-{ }^{t} \mathrm{Bu}$-phenyl, a dianionic alkyl-amide ligand is formed via $\mathrm{C}-\mathrm{H}$ activation across a transient In- $\mathrm{N}_{\text {imide }}$ bond. Reducing the size of the R-group to 2,4,6-trimethylphenyl (mesityl, Mes) enables oxidation of the indium and elimination of dinitrogen to afford the imide species, $K\left[\ln \left(\mathrm{NON}^{\mathrm{Ar}}\right)(\mathrm{NMes})\right]$. The anion contains a short $\mathrm{In}-\mathrm{N}_{\text {imide }}$ bond, shown computationally to contain appreciable multiple bond character. Reaction of isolated imides with an additional equivalent of azide $\left(\mathrm{R}=\mathrm{Mes}, \mathrm{SiMe}_{3}\right)$ generates tetrazenido-indium compounds $K\left[\ln \left(\mathrm{NON}^{\mathrm{Ar}}\right)\left\{\kappa-N, N^{\prime}-\mathrm{N}_{4}(\mathrm{Mes})(\mathrm{R})-1,4\right\}\right]$, shown by $X$-ray crystallography to contain planar $\ln \mathrm{N}_{4}$ heterocycles in the anion.
\end{abstract}

\section{Introduction}

Low valent compounds of the group 13 elements aluminium, gallium and indium exhibit a wide range of chemical reactivity. ${ }^{1}$ When present in the +1 oxidation-state, ${ }^{2}$ the electronconfiguration of the metallic element implies the presence of a lone-pair of electrons in an $n$ s orbital, prompting comparisons with neutral group 14 carbenoid species. ${ }^{3}$ Consequently, a rich area of coordination chemistry has developed, particularly focussed on the $\mathrm{Ga}(\mathrm{I})$ compounds. ${ }^{4}$ In addition to the ability of these compounds to behave as ligands, the lighter homologues are potent reducing agents, readily giving up two electrons to attain a more stable +3 oxidation-state. This reactivity has been harnessed in a wide range of chemical reactions, ${ }^{5}$ many of which are unique to this class of compound. ${ }^{6}$

The most common members of this class of compound are represented by the general formula $\mathrm{M}(\mathrm{X})$, where the charge on the metal is balanced by a mono-anionic ligand, $[\mathrm{X}]^{-}$. These ligands are typically bulky, a requirement to limit (or prevent) aggregation and protect the metal from unwanted redox chemistry. This concept is best illustrated in the context of this work by the series $\mathrm{M}\left(\mathrm{BDI}^{\mathrm{Ar}}\right)$ (BDI $=\beta$-diketiminate, $\left.[\mathrm{HC}(\mathrm{CMeNAr})]^{-}, \mathrm{Ar}=2,6-{ }^{\mathrm{i}} \mathrm{Pr}_{2} \mathrm{C}_{6} \mathrm{H}_{3}\right)$, for which mono-metallic $\mathrm{Al},{ }^{5 f} \mathrm{Ga}^{5 d}$ and $\mathrm{In}^{5 a}$ compounds are known.

School of Chemical and Physical Sciences, Victoria University of Wellington, P. O. Box 600, Wellington, New Zealand. E-mail: martyn.coles@vuw.ac.nz

$\uparrow$ Electronic supplementary information (ESI) available: Full experimental details, copies of NMR spectra, details of X-ray experiments and additional figures, $x y z$-coordinates from DFT calculations. CCDC 1863650-1863661. For ESI and crystallographic data in CIF or other electronic format see DOI: 10.1039/c8sc04078h
A recent development in the chemistry of mono-valent aluminium and indium is to employ a dianionic ligand $\left[\mathrm{X}_{2}\right]^{2-}$ to support $\mathrm{M}(\mathrm{I})$ metal centres, generating an overall negative charge on the metal-containing species, $\left[\mathrm{M}\left(\mathrm{X}_{2}\right)\right]^{-}$. Whilst this class of compound has been well studied for gallium, ${ }^{4 a, 4 b, 7}$ the corresponding aluminyl- ${ }^{8}$ and indyl ${ }^{9}{ }^{9}$ anions have only been recently isolated (Fig. 1), and hence the chemistry of these compounds is in its infancy. ${ }^{10}$ Initial studies of $\left[\mathrm{Al}\left(\mathrm{X}_{2}\right)\right]^{-}$and $\left[\operatorname{In}\left(\mathrm{X}_{2}\right)\right]^{-}$systems indicate significant lone-pair character at the metal (from DFT calculations), with preliminary reactivity consistent with an $\mathrm{Al}(\mathrm{I})$ or $\mathrm{In}(\mathrm{I})$ nucleophile. We report in this contribution an investigation of the reducing potential of a new potassium indyl compound towards organic azides. This class of substrate was selected to target synthetically challenging indium imide species.

Monomeric group 13 metal imides $[\mathrm{M}(\mathrm{X})(\mathrm{NR})]_{n}(\mathrm{X}=$ ancillary ligand; $\mathrm{M}=\mathrm{Al}, \mathrm{Ga}$ or $\mathrm{In} ; \mathrm{R}=$ organic fragment; $n=1$ ) are of academic and practical interest in several research areas. They formally contain metal-nitrogen multiple-bonds, ${ }^{11}$ and are implicated as intermediates in the formation of electronically important AlN, GaN and InN materials. ${ }^{12}$ Isolation of these
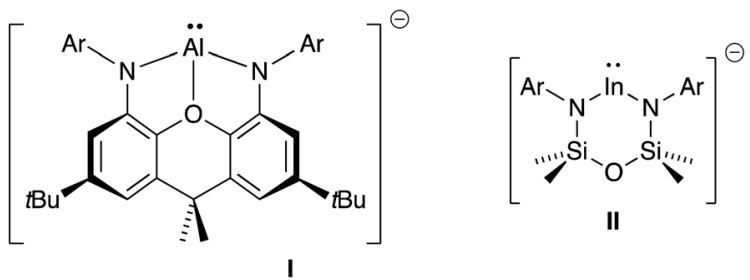

Fig. 1 The first reported aluminyl- and indyl-anions $(\mathrm{Ar}=$ 2,6- ${ }^{\mathrm{i}} \mathrm{Pr}_{2} \mathrm{C}_{6} \mathrm{H}_{3}$ ). 
compounds remains, however, synthetically challenging and only five examples have been crystallographically characterized since the first structural report in 2001 (III-VI, Fig. 2). ${ }^{13}$ Furthermore, these unusual compounds are restricted to a single example of an indium imide (VIb). ${ }^{\mathbf{1 3 d}}$ Structural characterization showed that the In-N bond distance in VIb (1.928(3) ^) was significantly shorter than the range observed for monomeric In amides (2.05-2.09 $\AA$ ), and that the C-In-N-C core adopted a trans-bent geometry. These data were consistent with In-N multiple bond character.

The isolation of III-VI was achieved through kinetic stabilization of the $\mathbf{M}-\mathrm{N}_{\text {imide }}$ bonds using sterically demanding ligands that prevent formation of ring- and cage-structures containing $\mu_{2}$ - and $\mu_{3}$-NR ligands. ${ }^{14}$ A major limitation of this approach is that the bulk required to protect the imide bond from intermolecular aggregation renders it inaccessible to potential substrates, preventing any coherent study of its reactivity. It is encouraging to note, however, that in the absence of external substrates, intramolecular activation of ligand substituents can occur. This strongly suggests that once formed, the $\mathrm{M}-\mathrm{N}_{\text {imide }}$ functional group is highly reactive. ${ }^{15}$

A general synthetic methodology to group 13 imides is the reduction of organic azides by a monovalent $\mathrm{M}(\mathrm{I})$ metal complexes (Scheme 1). ${ }^{\mathbf{1 3 b - \boldsymbol { d } \mathbf { 1 6 }}}$ These reactions proceed with elimination of $\mathrm{N}_{2}$ and oxidation of the metal $\mathrm{M}$ (III), which occurs with a concurrent increase in the coordination number of the metal. It is of note that, if insufficient steric protection is provided during synthesis, in situ addition of unreacted azide in the reaction mixture to the transient ' $M=N R$ ' bonds can occur (Scheme 1). ${ }^{17}$ For $\mathrm{Al}$ and $\mathrm{Ga}$, this has enabled the isolation of metallotetrazenes VII (also referred to as metal-containing tetrazoles), ${ }^{17,18}$ which are rationalized as the product of a $(2+3)$ cycloaddition. This chemistry has not been extended to indium.

In this contribution we report a new potassium indyl salt and its controlled (stepwise) reactivity with organic azides. The initial products are characterised as a new class of anionic indium(III) imide, shown crystallographically and computationally to contain In- $\mathrm{N}_{\text {imide }}$ multiple bonds. Reaction of
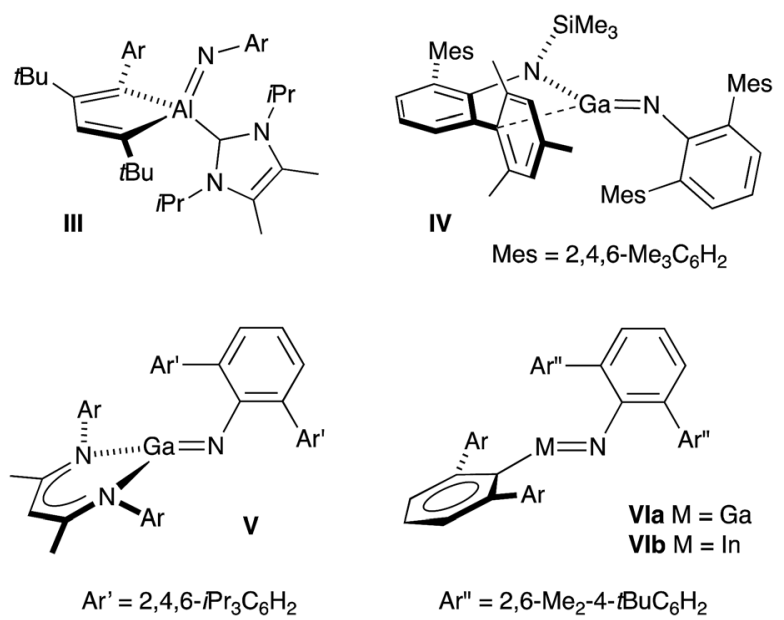

Fig. 2 Structurally characterized monomeric compounds of $\mathrm{Al}$, Ga and In containing unsupported $\mathrm{M}-\mathrm{N}_{\text {imide }}$ bonds.

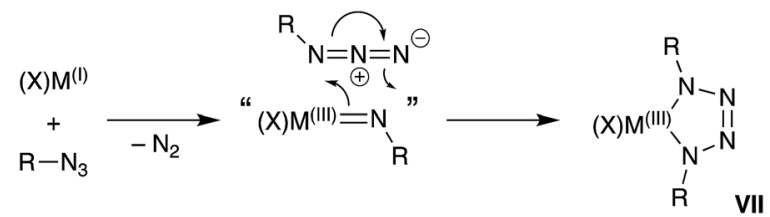

Scheme 1 Synthesis of group 13 metal-imides from organic azides and proposed conversion to metallotetrazenes (VII).

isolated examples with additional azide proceeds via a $(2+3)$ cycloaddition pathway to generate tetrazenido-indium salts, containing the first structurally characterized examples of the $\mathrm{InN}_{4}$-heterocycle.

\section{Results and discussion}

\section{Synthesis of a new potassium indyl salt}

The $\mathrm{NON}^{\mathrm{Ar}}$-ligand $\left(\mathrm{NON}^{\mathrm{Ar}}=\left[\mathrm{O}\left(\mathrm{SiMe}_{2} \mathrm{NAr}\right)_{2}\right]^{2-} ; \mathrm{Ar}=\right.$ 2,6- ${ }^{\mathrm{i}} \mathrm{Pr}_{2} \mathrm{C}_{6} \mathrm{H}_{3}$ ) stabilizes anionic indyl species as the indyllithium complex In( $\left.\mathrm{NON}^{\mathrm{Ar}}\right)\left(\mathrm{Li}\{\mathrm{THF}\}_{3}\right)$, or in the ion-separated salt $\left[\mathrm{K}(\right.$ crypt-222) $]\left[\mathrm{In}\left(\mathrm{NON}^{\mathrm{Ar}}\right)\right]$ (crypt-222 $=[2.2 .2]$-cryptand $) .{ }^{9}$ Reactivity studies of these species have been hampered by their inherent instability, prompting us to examine an alternative source of the indyl anion. A modified procedure was therefore developed that avoids lithium reagents, and does not require the use of expensive crypt-222 reagents to stabilize the salt.

The dipotassium salt, $\mathrm{K}_{2}\left[\left(\mathrm{NON}^{\mathrm{Ar}}\right)(\mathrm{THF})_{n}\right]$ (1), is readily obtained from the reaction of $\mathrm{KH}$ with the ligand pre-cursor $\left(\mathrm{NON}^{\mathrm{Ar}}\right) \mathrm{H}_{2} \cdot{ }^{19} \mathrm{NMR}$ analysis of the freshly prepared salt is consistent with incorporation of a single molecule of THF ( $n=$ 1 ), and the reagent can be used without further purification. However, crystallization from THF affords the Tris-THF adduct $(n=3)$ which forms a dimer $\left[\mathbf{1}_{-}\{\mathrm{THF}\}_{3}\right]_{2}$ in the solid-state (Fig. S3 $\dagger$ ). The potassium salt can also be isolated as the bisdiethylether adduct $\mathrm{K}_{2}\left[\left(\mathrm{NON}^{\mathrm{Ar}}\right)\left(\mathrm{Et}_{2} \mathrm{O}\right)_{2}\right]$ which forms a polymer in the solid-state (Fig. S4 $\dagger$ ), or as the 18-crown-6 (18-c-6) adduct that crystallizes as the dimer $\left[\mathrm{K}_{2}\left\{\left(\mathrm{NON}^{\mathrm{Ar}}\right)(18-c-6)\right]_{2}\right.$ (Fig. S5 $\left.\dagger\right)$.

The reaction of 1 with $\mathrm{InCl}_{3}$ affords a new indium-containing complex, 2. The NMR spectra show a symmetrical environment for the ligand backbone with a single peak for the $\mathrm{SiMe}_{2}$ groups. Although this is consistent with the three-coordinate species 'In $\left(\mathrm{NON}^{\mathrm{Ar}}\right) \mathrm{Cl}$ ', elemental analysis was inconsistent with this formula and the compounds was therefore analysed by singlecrystal X-ray diffraction (Fig. 3 and Table 1).

The asymmetric unit of 2 contains the four-coordinate indium anion $\left[\operatorname{In}\left(\mathrm{NON}^{\mathrm{Ar}}\right) \mathrm{Cl}_{2}\right]^{-}$(Fig. 3a). The charge is balanced by a potassium atom that forms $\pi$-aryl interactions with an Ar-groups of the diamide ligand, and has a close-contact with a chloride ligand. The crystal structure shows a 1-D polymer $[2]_{n}$ with additional interactions between the K-atom and aryl-/chloride groups from neighbouring molecules (Fig. 3b).

Reduction of 2 with two equivalents of potassium yields the new indyl compound $\mathrm{K}\left[\mathrm{In}\left(\mathrm{NON}^{\mathrm{Ar}}\right)\right]$ (3) as a hexane soluble, yellow solid. The ${ }^{1} \mathrm{H}$ NMR spectrum of $\mathbf{3}$ displays a single resonance for the $\mathrm{SiMe}_{2}$ substituents, indicative of a symmetrical environment for the $\mathrm{NON}^{\mathrm{Ar}}$-ligand. There are no resonances attributable to In-H hydride ligands (Fig. S10†). ${ }^{20}$ 


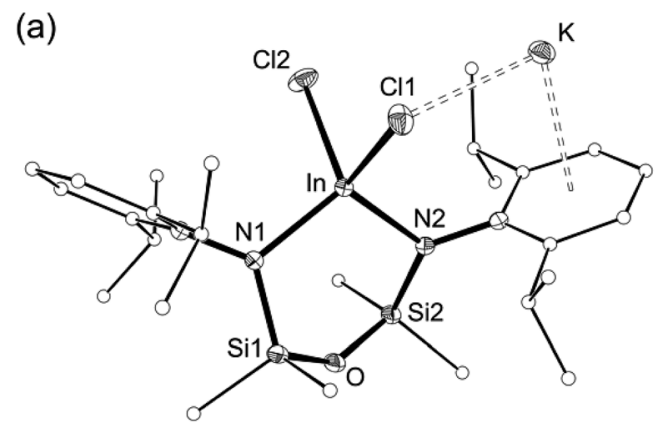

(b)

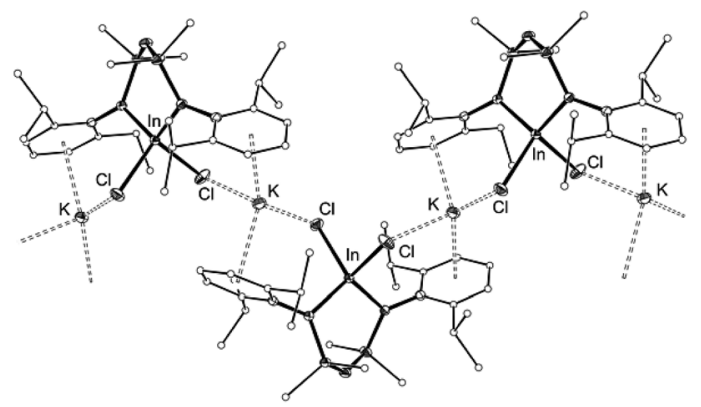

Fig. 3 (a) Displacement ellipsoid plot (30\% probability, carbon atoms reduced, hydrogen atoms omitted) of $K\left[\operatorname{In}\left(\mathrm{NON}^{\mathrm{Ar}}\right) \mathrm{Cl}_{2}\right]$ (2). (b) Segment of polymeric chain $\left(\cdots[2]_{3} \cdots\right)$, showing intermolecular $\mathrm{K} \cdots \mathrm{Cl}$ and $\mathrm{K} \cdots \mathrm{C}$ interactions.

Table 1 Selected bond length $(\AA)$ and angles $\left(^{\circ}\right)$ for $\mathrm{K}\left[\ln \left(\mathrm{NON}^{\mathrm{Ar}}\right) \mathrm{Cl}_{2}\right]$ (2) and $\left[\mathrm{K}\left\{\ln \left(\mathrm{NON}^{\mathrm{Ar}}\right)\right\}\right]_{2}\left([3]_{2}\right)$

\begin{tabular}{lll}
\hline Compound & 2 & {$[3]_{2}$} \\
\hline $\mathrm{In}^{a}-\mathrm{N} 1$ & $2.0820(17)$ & $2.222(3)$ \\
$\mathrm{In}^{a}-\mathrm{N} 2$ & $2.0826(17)$ & $2.193(2)$ \\
$\mathrm{In} 2-\mathrm{N} 3$ & - & $2.240(3)$ \\
$\mathrm{In} 2-\mathrm{N} 4$ & - & $2.182(3)$ \\
$\mathrm{In}-\mathrm{Cl} 1$ & $2.3977(5)$ & - \\
$\mathrm{In}-\mathrm{Cl} 2$ & $2.4010(6)$ & - \\
$\mathrm{N} 1-\mathrm{In}{ }^{a}-\mathrm{N} 2$ & $107.57(7)$ & $98.43(9)$ \\
$\mathrm{N} 3-\mathrm{In} 2-\mathrm{N} 4$ & - & $98.24(9)$ \\
${ }^{a} 2=\mathrm{In},[3]_{2}=\mathrm{In} 1$. & & \\
\end{tabular}

The molecular structure of 3 (Fig. 4) is reminiscent of the recently reported aluminyl anion. ${ }^{8}$ The asymmetric unit consists of two $\left[\mathrm{In}\left(\mathrm{NON}^{\mathrm{Ar}}\right)\right]^{-}$anions linked by potassium cations that are involved in $\pi$-aryl interactions to flanking Ar groups

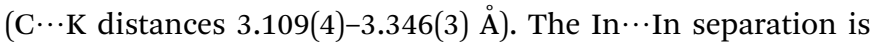
$4.710(3) \AA$, with In-N bond lengths (2.182(3)-2.240(3) $\mathrm{A})$ consistent with anionic In(I) metal centres. ${ }^{9}$ There are no bonding interactions between the indium and the oxygen-atom of the backbone ( $\mathrm{In} \cdots \mathrm{O}=3.557(2)$ and $3.577(2) \AA$ ), consistent with a strictly two-coordinate indyl anion.

\section{Reactivity of the indyl anion with organic azides}

Our initial attempt to isolate an imide from 3 was made using an equimolar amount of the sterically demanding 2,6-

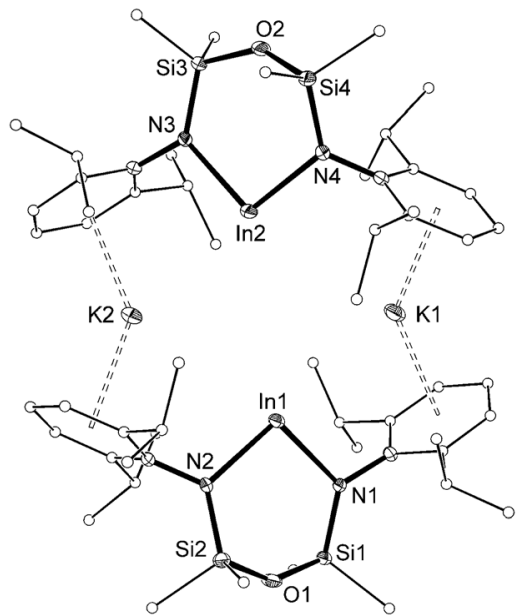

Fig. 4 Displacement ellipsoid plot (30\% probability, carbon atoms reduced, hydrogen atoms omitted) of $\left[K\left\{\ln \left(\mathrm{NON}^{\mathrm{Ar}}\right)\right\}\right]_{2}\left([3]_{2}\right)$.

bis(diphenylmethyl)-4- ${ }^{t} \mathrm{Bu}$-phenyl azide $\left(\mathrm{Ar}^{t} \mathrm{~N}_{3}\right.$, Scheme 2). The reagents were combined at $-78{ }^{\circ} \mathrm{C}$, allowed to warm to room temperature and stir for $1 \mathrm{~h}$. The ${ }^{1} \mathrm{H}$ NMR spectrum of colourless crystals 4 obtained on workup showed a loss symmetry for the NON-backbone $\left(\delta_{\mathrm{H}} 0.58\right.$ and $\left.0.45,6 \mathrm{H}, \mathrm{SiMe}_{2}\right)$ and a reduction in the intensity of the $\mathrm{CHPh}_{2}$ resonance $\left(\delta_{\mathrm{H}} 5.56,1 \mathrm{H}\right)$. A new peak at $3.24 \mathrm{ppm}$ (with no corresponding carbon resonance in HSQC experiments, Fig. S15 ${ }^{\dagger}$ ) is assigned to an $\mathrm{NH}$ functionality.

The structure of $\mathbf{4}$ was determined by X-ray diffraction and shows a $\kappa^{2}-\mathrm{C}, \mathrm{N}-\mathrm{N}(\mathrm{H})\left\{\mathrm{C}_{6} \mathrm{H}_{2}\left(\mathrm{CPh}_{2}\right)\left(\mathrm{CHPh}_{2}\right)-{ }^{t} \mathrm{Bu}-2,6,4\right\}$ ligand chelating to a four-coordinate, anionic indium(III) centre (Fig. 5 and Table 2). The potassium counterion is located between two aryl-substituents of the alkyl-amido ligand $(\mathrm{C} \cdots \mathrm{K}$ distances 3.148(2)-3.581(2) ̊). The In-N3 distance $(2.1855(14) \AA)$ is consistent with a single bond to an amide nitrogen, and the location of electron density assigned to H1x in the difference map further supports this conclusion. Similar intramolecular activation has been observed at $\mathrm{Al}^{21}$ and $\mathrm{Sn}^{22}$ amido derivatives of the $\mathrm{Ar}^{\ddagger}$ group, although in these instances the mechanism leading to the products are not known. We propose that formation of $\mathbf{4}$ occurs via intramolecular addition of a methine

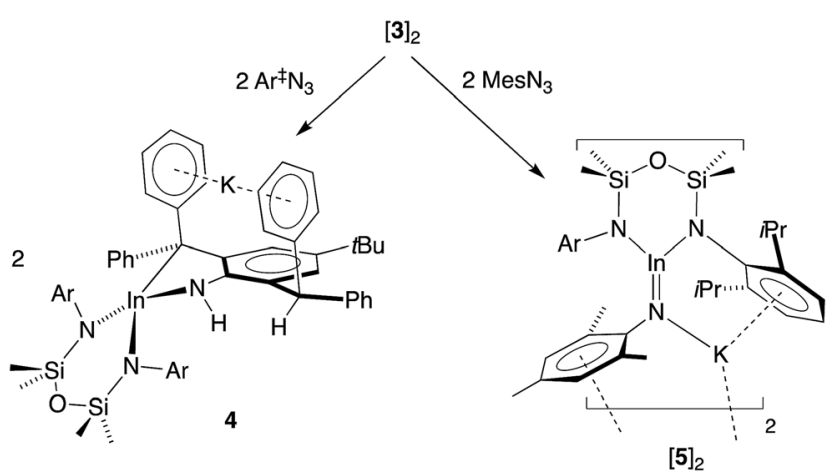

Scheme 2 Structurally characterized monomeric complexes of Al, Ga and In containing unsupported $\mathrm{M}-\mathrm{N}_{\text {imide }}$ bonds. 


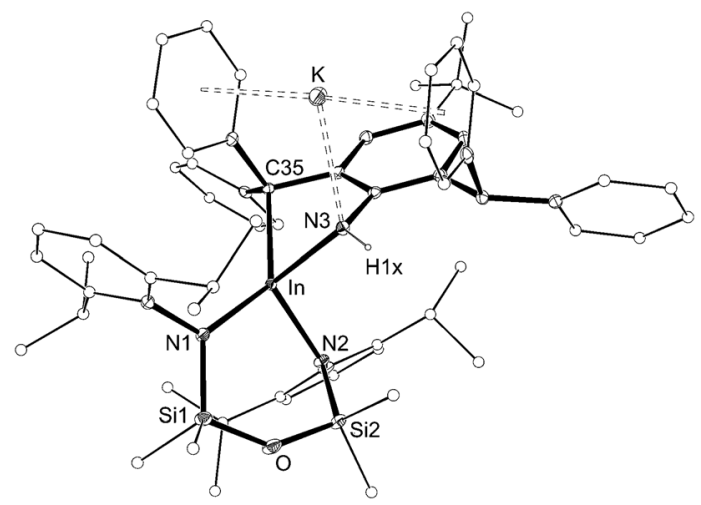

Fig. 5 Displacement ellipsoid plot (30\% probability, carbon atoms reduced, hydrogen atoms omitted) of $K\left[\ln \left(\mathrm{NON}^{\mathrm{Ar}}\right)\left(\kappa^{2}-\mathrm{C}, \mathrm{N}-\mathrm{N}(\mathrm{H})\left\{\mathrm{C}_{6}{ }^{-}\right.\right.\right.$ $\left.\left.\left.\mathrm{H}_{2}\left(\mathrm{CPh}_{2}\right)\left(\mathrm{CHPh}_{2}\right)-{ }^{t} \mathrm{Bu}-2,6,4\right\}\right)\right](4)$.

Table 2 Selected bond length $(\AA)$ and angles $\left(^{\circ}\right)$ for $\mathrm{K}\left[\ln \left(\mathrm{NON}^{\mathrm{Ar}}\right)\left(\kappa^{2}-\right.\right.$ $\left.\left.\mathrm{C}, \mathrm{N}-\mathrm{N}(\mathrm{H})\left\{\mathrm{C}_{6} \mathrm{H}_{2}\left(\mathrm{CPh}_{2}\right)\left(\mathrm{CHPh}_{2}\right)-{ }^{\mathrm{t}} \mathrm{Bu}-2,6,4\right\}\right)\right]$ (4)

\begin{tabular}{llll}
\hline In-N1 & $2.1674(14)$ & In-N2 & $2.1676(14)$ \\
In-N3 & $2.1855(14)$ & In-C35 & $2.2875(16)$ \\
N1-In-N2 & $102.24(5)$ & N1-In-N3 & $112.64(5)$ \\
N2-In-N3 & $106.25(5)$ & N1-In-C35 & $132.97(6)$ \\
N2-In-C35 & $119.53(6)$ & N3-In-C35 & $77.12(6)$
\end{tabular}

$\mathrm{CHPh}_{2}$ across the reactive ' $\mathrm{In}=\mathrm{NAr}^{\mathrm{t}}$ ' bond of a transient indium imide. ${ }^{15 b}$

To mitigate complications from ligand activation, the reaction was repeated with the sterically less intrusive 2,4,6-trimethylphenyl azide (mesityl azide, $\mathrm{MesN}_{3}$ ) under the conditions described above (Scheme 2). Concentration of the resulting solution and storage at $-30{ }^{\circ} \mathrm{C}$ gave deep orange crystals (5). The ${ }^{1} \mathrm{H}$ NMR spectrum is consistent with a symmetrical NONbackbone $\left(\delta_{\mathrm{H}} 0.33,12 \mathrm{H}, \mathrm{SiMe}_{2}\right)$ and a freely rotating Mes group $\left(\delta_{\mathrm{H}} 1.57,6 \mathrm{H}, 2,6-\mathrm{C}_{6} \mathrm{H}_{2} \mathrm{Me}_{2}\right)$.

The solid-state structure of $\mathbf{5}$ confirmed the formation of an imido-indium complex (Fig. 6 and Table 3). The compound crystallizes as the non-symmetry related dimer $[5]_{2}$, with the potassium counter-ions involved in $\pi$-aryl interactions with $\mathrm{Ar}$

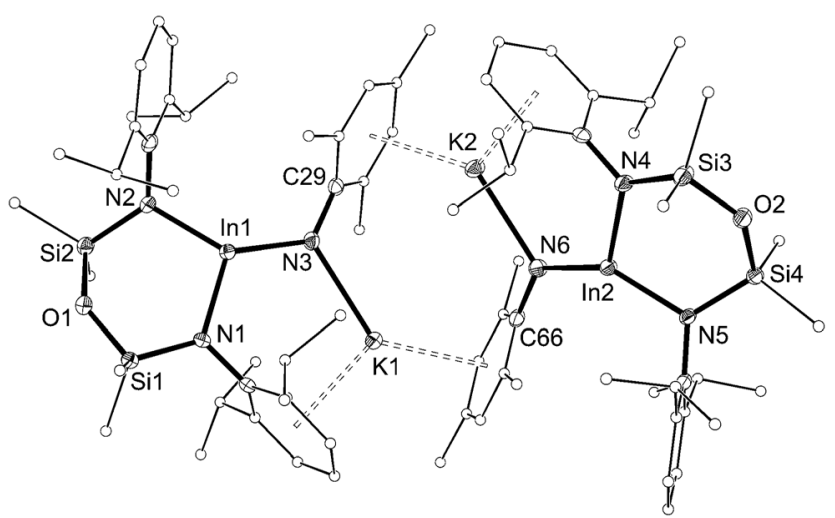

Fig. 6 Displacement ellipsoid plot (30\% probability, carbon atoms reduced, hydrogen atoms omitted) of $\left[K\left\{\ln \left(\mathrm{NON}^{\mathrm{Ar}}\right)(\mathrm{NMes})\right\}\right]_{2}\left([5]_{2}\right)$.
Table 3 Selected bond length $(\AA)$ and angles $\left({ }^{\circ}\right)$ for $[K$ $\left.\left\{\ln \left(\mathrm{NON}^{\mathrm{Ar}}\right)(\mathrm{NMes})\right\}\right]_{2}\left([5]_{2}\right)$ and $[K(\mathrm{crypt}-222)]\left[\ln \left(\mathrm{NON}^{\mathrm{Ar}}\right)(\mathrm{NMes})\right](6)$

\begin{tabular}{lll}
\hline Compound & {$[5]_{2}$} & 6 \\
\hline $\mathrm{In}^{a}-\mathrm{N} 1$ & $2.090(2)$ & $2.1026(16)$ \\
$\mathrm{In}^{a}-\mathrm{N} 2$ & $2.077(2)$ & $2.1152(16)$ \\
$\mathrm{In}^{a}-\mathrm{N} 3$ & $1.986(2)$ & - \\
$\mathrm{In} 2-\mathrm{N} 4$ & $2.097(2)$ & - \\
$\mathrm{In} 2-\mathrm{N} 5$ & $2.082(2)$ & - \\
$\mathrm{In} 2-\mathrm{N} 6$ & $1.999(2)$ & $100.36(6)$ \\
$\mathrm{N} 1-\mathrm{In}^{a}-\mathrm{N} 2$ & $104.85(10)$ & $125.54(7)$ \\
$\mathrm{N} 1-\mathrm{In}^{a}-\mathrm{N} 3$ & $115.80(10)$ & - \\
$\mathrm{N} 2-\mathrm{In}{ }^{a}-\mathrm{N} 3$ & $138.01(10)$ & - \\
$\mathrm{N} 4-\mathrm{In} 2-\mathrm{N} 5$ & $102.70(9)$ & - \\
$\mathrm{N} 4-\mathrm{In} 2-\mathrm{N} 6$ & $115.29(10)$ & \\
$\mathrm{N} 5-\mathrm{In} 2-\mathrm{N} 6$ & $140.66(10)$ & \\
${ }^{a}[5]_{2}=\mathrm{In} 1,6=\mathrm{In}$. & &
\end{tabular}

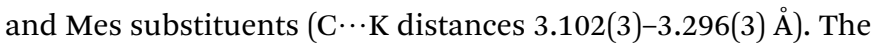
indium centres are distorted trigonal planar $\left(\Sigma_{\text {angles }} 358.7^{\circ}\right)$, with In- $\mathrm{N}_{\text {imide }}$ bond lengths of 1.986(2) and 1.999(2) A to N3 and N6, respectively. These represent an average shortening of $3.6 \%$ compared with the In- $\mathrm{N}$ bonds in the three coordinate amide In(NHMes $\left.{ }^{*}\right)_{3}\left(\mathrm{Mes}^{*}=2,4,6{ }^{t}{ }^{\mathrm{B}} \mathrm{Bu}_{3} \mathrm{C}_{6} \mathrm{H}_{2}\right),{ }^{23}$ although are longer than the neutral imide complex VIb $(1.928(3) \AA)^{13 d}$ in which the metal is two-coordinate. The imido-nitrogen atoms are bent, with In-N-C angles of $123.9(2)^{\circ}$ and $123.8(2)^{\circ}$ at N3 and N6, respectively.

The length of the In- $\mathrm{N}_{\text {imide }}$ bonds in $\mathbf{5}$ may be influenced by interactions with the potassium cations (N3-K1 2.661(3) ̊, N6K2 2.646(3) ̊), which are located closer to the nitrogen atom than in other potassiated imides (range 2.732(3)-3.069(11) $\AA^{24}{ }^{24}$ To isolate the imido-bond from $\mathrm{N} \cdots \mathrm{K}$ interactions, 5 was crystallized in the presence of [2.2.2]-cryptand. The crystal structure of the product confirmed formation of the separated ion-pair [K(crypt-222)][In(NON $\left.\left.{ }^{\mathrm{Ar}}\right)(\mathrm{NMes})\right]$ (6, Fig. 7). Interestingly the In- $\mathrm{N}_{\text {imide }}$ bond length $(1.9907(18) \AA$ ) remains unchanged (within $3 \sigma$ ) and the In-N-C angle is still bent (In-N3-C29 $\left.127.43(14)^{\circ}\right)$, suggesting that the $\mathrm{N} \cdots \mathrm{K}$ interactions in 5 have

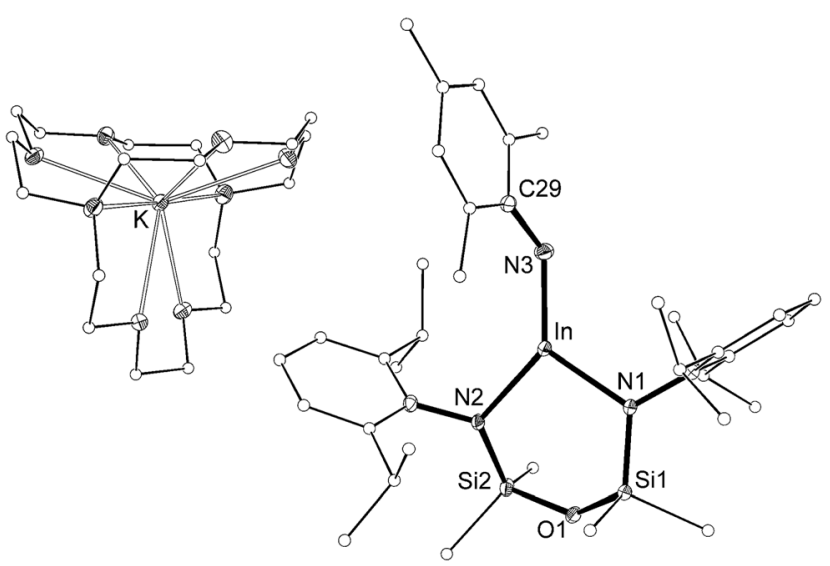

Fig. 7 Displacement ellipsoid plot (30\% probability, carbon atoms reduced, hydrogen atoms omitted) of [K(crypt-222)][In(NON $\left.\left.{ }^{\mathrm{Ar}}\right)(\mathrm{NMes})\right]$ (6). 
little effect on the structural component of the indium-nitrogen bond.

\section{Computational analysis of $\mathbf{I n}-\mathbf{N}_{\text {imide }}$ bond}

Optimisation and subsequent analysis using density functional theory confirmed the multiple-bond character of the In $-\mathrm{N}_{\text {imide }}$ unit in 5 and the isolated anion $\left[\operatorname{In}\left(\mathrm{NON}^{\mathrm{Ar}}\right)(\mathrm{NMes})\right]^{-}$from compound $6\left([6]^{-}\right.$) (see ESI $\dagger$ ). This is clearly demonstrated from the increased Wiberg bond orders for this group $\left(5,0.59 ;[6]^{-}\right.$ 0.71 ) that are substantially higher than the In-N bonds to the $\mathrm{NON}^{\mathrm{Ar}}$-ligand (5, 0.22/0.29; $\left.[6]^{-}, 0.25\right)$.

To explore the nature of this bond in more detail, plausible resonance structures analogous to those examined for $\mathbf{V I b},{ }^{13 d}$ were submitted for NBO calculations (A-D, Scheme 3). The quality criterion used to compare results calculated for the different resonance structures is the percentage of non-Lewis (n-L) components, where a lower non-Lewis percentage indicates a better representation. Resonance form $\mathbf{C}$ did not yield a viable solution by this method. However, structures A (triple bond), B (double bond) and $\mathbf{D}$ (single bond) all have a low $\mathrm{n}-\mathrm{L}$ contribution to their overall NBO solution (Table S2†). The best localisations were achieved for multiple-bonded $\mathbf{A}$ and $\mathbf{B}$ (n$\mathrm{L}=1.965 \%$ and $1.990 \%$ respectively), while $\mathbf{D}$ was only slightly less well localised ( $\mathrm{n}-\mathrm{L}=2.094 \%$ ). Although it is difficult to extract a precise numerical value for the multiplicity of the In$\mathrm{N}_{\text {imide }}$ bond from these computational data, the results confirm a strong multiple-bond component in accordance with crystallographic results, and observed reactivity (vide infra).

Quantum Theory of Atoms In Molecules (QTAIM) analysis of 5 and $[6]^{-}$has been performed. The bond critical point between the In and $\mathrm{N}_{\text {imide }}$ bonds have a low ellipiticity $(\varepsilon)$ of 0.079 and 0.072 for 5 and $[6]^{-}$, respectively, inconsistent with a conventional $\mathrm{In}=\mathrm{N}$ double where a larger value $(>0.25)$ is predicted. These data suggest a non-elliptical cross-section of electron density in the In-N bond vector. This is consistent with a model proposed by Power and co-workers in related gallium imides related to $\mathbf{V I a},{ }^{13 b}$ in which an organogallium(I) species interacts with a singlet nitrene, with incomplete donation of electron pairs (represented by dashed lines in Fig. 8).

\section{Reactivity of indium imides with organic azides}

As the imido-mesityl substituents are considerably less bulky than the terphenyl groups in IV-VI, we wished to determine whether the In- $\mathrm{N}_{\text {imide }}$ bond in $\mathbf{5}$ was available for controlled

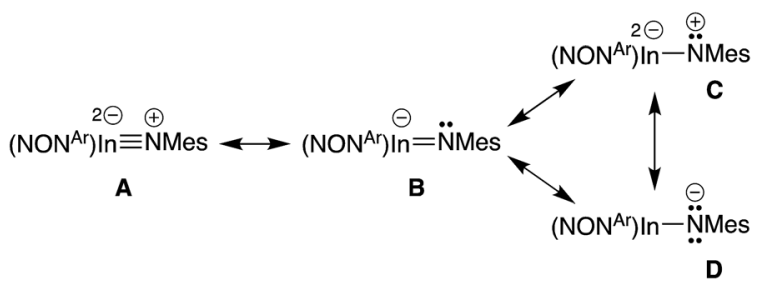

Scheme 3 Possible resonance structures for indium imide anions.

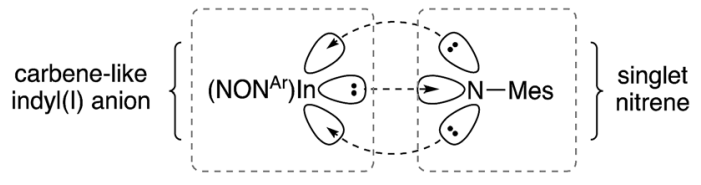

Fig. 8 Proposed bonding model for $\mathrm{In}-\mathrm{N}_{\text {imide }}$ interaction in $[6]^{-}$, based on a model proposed Power and by co-workers (see ref. 13b).

reactivity studies. Inspired by the proposed formation of metallotetrazenes from group 13 metal imides (Scheme 1), we investigated the reactivity of isolated samples of $\mathbf{5}$ with organic azides $\mathrm{RN}_{3}\left(\mathrm{R}=\right.$ Mes, $\left.\mathrm{SiMe}_{3}\right)$.

Addition of a solution of $\mathrm{RN}_{3}$ to an orange solution of 5 at room temperature resulted in decolorization over an approximate 5 minute period (Scheme 4). NMR spectra show changes corresponding to the addition of mesityl (7) or $\mathrm{SiMe}_{3}$ (8) groups, consistent with their incorporation in the product. In agreement with these data, the composition of the products as the first examples of indium tetrazenido compounds was confirmed by X-ray crystallography (Fig. 9 and 10, Table 4). These results demonstrate that in this instance, the potassium atoms in $\mathbf{5}$ do not adversely affect the reactivity of the $\mathrm{In}-\mathrm{N}_{\text {imide }}$ bond. We therefore propose that 5 behaves chemically as ' $I n=$ NMes', and

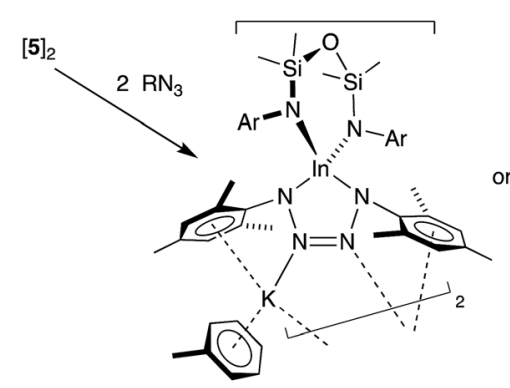

$[7 \cdot(\text { toluene })]_{2}(\mathrm{R}=\mathrm{Mes})$

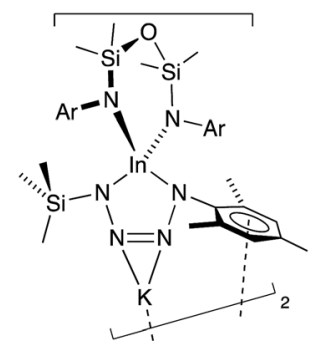

$[8]_{2}\left(\mathrm{R}=\mathrm{SiMe}_{3}\right)$
Scheme 4 Reaction of $\mathrm{K}\left[\ln \left(\mathrm{NON}^{\mathrm{Ar}}\right)(\mathrm{NMes})\right]$ (5) with $\mathrm{RN}_{3}(\mathrm{R}=$ Mes, $\mathrm{SiMe}_{3}$.

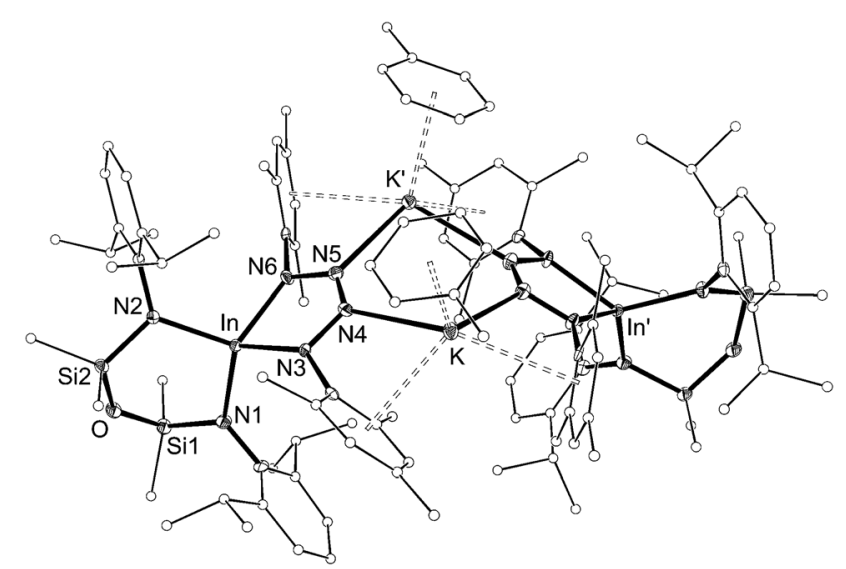

Fig. 9 Displacement ellipsoid plot (30\% probability, carbon atoms reduced, hydrogen atoms omitted) of $\left[K\left\{\ln \left(\mathrm{NON}^{\mathrm{Ar}}\right)\left(\kappa-N, N^{\prime}-\mathrm{N}_{4}\{\mathrm{Mes}\}_{2}-\right.\right.\right.$ $\left.\left.\left.1,4)\left(\mathrm{C}_{7} \mathrm{H}_{8}\right)\right\}\right]_{2}([7 \cdot \text { (toluene })]_{2}\right)$. 


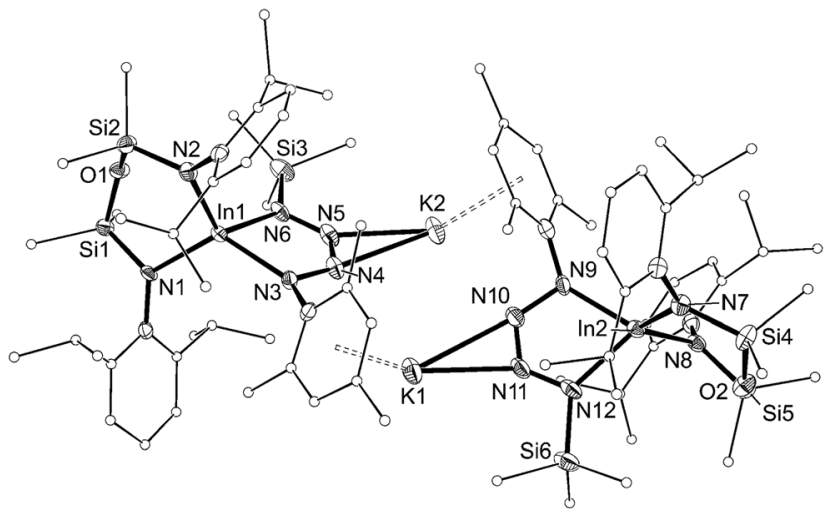

Fig. 10 Displacement ellipsoid plot (30\% probability, carbon atoms reduced, hydrogen atoms omitted) of $\left[K\left\{\ln \left(N O N^{A r}\right)\left(\kappa-N, N^{\prime}-N_{4}\{\right.\right.\right.$ Mes $\}$ $\left.\left.\left.\left\{\mathrm{SiMe}_{3}\right\}-1,4\right)\right\}\right]_{2}\left([8]_{2}\right)$.

Table 4 Selected bond length $(\AA)$ and angles $\left(^{\circ}\right)$ for $\left[K\left\{\ln \left(N O N^{A r}\right)(\kappa-\right.\right.$ $\left.\left.\left.N, N^{\prime}-\mathrm{N}_{4}\{\mathrm{Mes}\}_{2}-1,4\right)\left(\mathrm{C}_{7} \mathrm{H}_{8}\right)\right\}\right]_{2}\left([7 \cdot(\text { toluene })]_{2}\right)$ and $\left[K\left\{\ln \left(\mathrm{NON}^{\mathrm{Ar}}\right)\left(\kappa-N, N^{\prime}-\right.\right.\right.$ $\left.\left.\left.\mathrm{N}_{4}\{\mathrm{Mes}\}\left\{\mathrm{SiMe}_{3}\right\}-1,4\right)\right\}\right]_{2}\left([8]_{2}\right)$

\begin{tabular}{lll}
\hline Compound & {$[7 \cdot \text { (toluene) }]_{2}$} & {$[8]_{2}$} \\
\hline In $^{a}-\mathrm{N} 1$ & $2.143(4)$ & $2.137(5)$ \\
In $^{a}-\mathrm{N} 2$ & $2.134(4)$ & $2.117(5)$ \\
In $^{a}-\mathrm{N} 3$ & $2.127(4)$ & $2.116(5)$ \\
In $^{a}-\mathrm{N} 6$ & $2.140(4)$ & $2.147(5)$ \\
In2-N7 $^{\text {In2-N8 }}$ & - & $2.091(6)$ \\
In2-N9 & - & $2.132(5)$ \\
In2-N12 & - & $2.117(6)$ \\
N3-N4 & - & $2.146(6)$ \\
N4-N5 & $1.391(6)$ & $1.398(8)$ \\
N5-N6 & $1.273(6)$ & $1.277(9)$ \\
N9-N10 & $1.376(6)$ & $1.373(9)$ \\
N10-N11 & - & $1.402(8)$ \\
N11-N12 & - & $1.272(9)$ \\
N1-In ${ }^{a}-\mathrm{N} 2$ & - & $1.347(10)$ \\
N3-In ${ }^{-N} 6$ & $103.12(16)$ & $106.1(2)$ \\
N7-In2-N8 & $74.67(16)$ & $76.0(2)$ \\
N9-In2-N12 & & $105.8(2)$ \\
${ }^{a}\left[7 \cdot(\text { toluene) }]_{2}=\right.$ In1, 6 = In. & $74.9(2)$ \\
\end{tabular}

that the formation of the unsymmetrical tetrazene 8 strongly endorses the previously assumed $(2+3)$-cycloaddition pathway of transient imides.

The dimesityl derivative $[7 \cdot(\text { toluene })]_{2}$ lies on a two-fold rotation axis that forms a dimeric unit, with $\mathrm{K} \cdots \pi$-aryl interactions between Mes-groups and an incorporated toluene molecule that encapsulates the cation $(\mathrm{C} \cdots \mathrm{K}$ distances $3.006(5)-$ $3.993(5) \AA)$. Crystallization of $[7 \cdot \text { (toluene) }]_{2}$ in the presence of 18-crown-6 (18-c-6) disrupts dimer formation to afford [K(18-c$6)]\left[\operatorname{In}\left(\mathrm{NON}^{\mathrm{Ar}}\right)\left(\mathrm{N}_{4}\{\mathrm{Mes}\}_{2}-1,4\right)\right]$ (7 (18-c-6)). This salt forms a contact ion-pair linked by $\mathrm{K} \cdots \mathrm{N}$ interactions to the two central nitrogen atoms of the InN $_{4}$-tetrazene ring (2.820(2) $\AA$ and 2.939(2) A, Fig. S27†). The trimethylsilyl derivative $\mathrm{K}$ $\left.\left[\mathrm{In}\left(\mathrm{NON}^{\mathrm{Ar}}\right)\left(\mathrm{N}_{4}\left\{\mathrm{Mes}_{\{}\right\} \mathrm{SiMe}_{3}\right\}-1,4\right)\right]$ also crystallizes as the dimer $[8]_{2}$, with the potassium cations linking non-symmetry related units through a combination of $\mathrm{K} \cdots \mathrm{N}(2.641(6)-2.913(6) \AA)$ and $\mathrm{K} \cdots \pi$-aryl (3.024(9)-3.264(8) Å) interactions.

In all cases the anion comprises two approximately orthogonal rings fused at a four-coordinate indium centre. The metallotetrazene rings are essentially planar, with nitrogennitrogen bond lengths indicating double-bond character between atoms in the 3- and 4-positions of the heterocycle (see VII, Scheme 1). These parameters are consistent with neutral aluminum- ${ }^{17,18}$ and gallium- ${ }^{18 b}$ derivatives, although we note that compounds 7 and $\mathbf{8}$ represent the first structurally characterized indium compounds containing the tetrazenide ligand, and are unique examples where the $\mathbf{M N}_{4}$-heterocycle is a component of an anionic species.

\section{Conclusions}

This work describes the first detailed reactivity study of an indylanion. We confirm that the negative charge associated with the indium centre does not adversely affect their ability to act as a reducing agent towards organic azides. The reactions proceed cleanly with elimination of dinitrogen and oxidation of the indium(I) to In(III). The isolated compounds have been structurally verified as a new class of anionic indium imide, shown computationally to contain In- $\mathrm{N}_{\text {imide }}$ multiple bonds. Furthermore, we demonstrate that the reduced size of the imidesubstituent in this work compared with previous examples allows access to the In- $\mathrm{N}_{\text {imide }}$ bond, demonstrated by the reaction with additional equivalents of azide. The products from this $(2+3)$-cycloaddition are the first time that this reaction has been extended to indium, and crystallographic analysis confirms a planar $\mathrm{InN}_{4}$-heterocycle as a component of the anion.

\section{Conflicts of interest}

There are no conflicts to declare.

\section{Notes and references}

1 (a) T. Chu and G. I. Nikonov, Chem. Rev., 2018, 118, 36083680; (b) S. González-Gallardo, T. Bollermann, R. A. Fischer and R. Murugavel, Chem. Rev., 2012, 112, 3136-3170; (c) H. Schnöckel, Chem. Rev., 2010, 110, 4125-4163.

2 (a) Y. Segawa, M. Yamashita and K. Nozaki, Science, 2006, 314, 113-115; (b) T. B. Marder, Science, 2006, 314, 69-70.

3 M. Asay, C. Jones and M. Driess, Chem. Rev., 2011, 111, 354396.

4 (a) C. Jones, D. P. Mills, R. P. Rose and A. Stasch, Dalton Trans., 2008, 4395-4408; (b) G. Jin, C. Jones, P. C. Junk, A. Stasch and W. D. Woodul, New J. Chem., 2008, 32, 835842; (c) C. Jones, P. C. Junk, J. A. Platts and A. Stasch, J. Am. Chem. Soc., 2006, 128, 2206-2207.

5 (a) M. S. Hill and P. B. Hitchcock, Chem. Commun., 2004, 1818-1819; (b) M. S. Hill, P. B. Hitchcock and R. Pongtavornpinyo, Dalton Trans., 2005, 273-277; (c) M. S. Hill, P. B. Hitchcock and R. Pongtavornpinyo, Angew. Chem., Int. Ed., 2005, 44, 4231-4235; (d) N. J. Hardman, 
B. E. Eichler and P. P. Power, Chem. Commun., 2000, 19911992; (e) M. Stender and P. P. Power, Polyhedron, 2002, 21, 525-529; $(f)$ C. Cui, H. W. Roesky, H.-G. Schmidt, M. Noltemeyer, H. Hao and F. Cimpoesu, Angew. Chem., Int. Ed., 2000, 39, 4274-4276.

6 (a) M. S. Hill, P. B. Hitchcock and R. Pongtavornpinyo, Science, 2006, 311, 1904-1907; (b) A. V. Protchenko, D. Dange, J. R. Harmer, C. Y. Tang, A. D. Schwarz, M. J. Kelly, N. Phillips, R. Tirfoin, K. H. Birjkumar, C. Jones, N. Kaltsoyannis, P. Mountford and S. Aldridge, Nat. Chem., 2014, 6, 315.

7 (a) R. J. Baker, R. D. Farley, C. Jones, M. Kloth and D. M. Murphy, J. Chem. Soc., Dalton Trans., 2002, 38443850; (b) R. J. Baker, C. Jones and J. A. Platts, J. Am. Chem. Soc., 2003, 125, 10534-10535; (c) R. J. Baker, C. Jones and M. Kloth, Dalton Trans., 2005, 2106-2110; (d) S. Aldridge, R. J. Baker, N. D. Coombs, C. Jones, R. P. Rose, A. Rossin and D. J. Willock, Dalton Trans., 2006, 3313-3320; (e) R. J. Baker, C. Jones, D. P. Mills, D. M. Murphy, E. HeyHawkins and R. Wolf, Dalton Trans., 2006, 64-72; (f) O. Bonello, C. Jones, A. Stasch and W. D. Woodul, Organometallics, 2010, 29, 4914-4922; $(g)$ E. S. Schmidt, A. Jockisch and H. Schmidbaur, J. Am. Chem. Soc., 1999, 121, 9758-9759.

8 J. Hicks, P. Vasko, J. M. Goicoechea and S. Aldridge, Nature, 2018, 557, 92-95.

9 R. J. Schwamm, M. D. Anker, M. Lein, M. P. Coles and C. M. Fitchett, Angew. Chem., Int. Ed., 2018, 57, 5885-5887.

10 A. Hinz and F. Breher, Angew. Chem., Int. Ed., 2018, 57, 88188820 .

11 (a) R. C. Fischer and P. P. Power, Chem. Rev., 2010, 110, 38773923; (b) M. F. Lappert, P. P. Power, A. V. Protchenko and A. L. Seeber, Metal Amide Chemistry, Wiley, New York, 2009.

12 M. A. Malik, M. Afzaal and P. O'Brien, Chem. Rev., 2010, 110, 4417-4446.

13 (a) J. Li, X. Li, W. Huang, H. Hu, J. Zhang and C. Cui, Chem. Eur. J., 2012, 18, 15263-15266; (b) R. J. Wright, M. Brynda, J. C. Fettinger, A. R. Betzer and P. P. Power, J. Am. Chem. Soc., 2006, 128, 12498-12509; (c) N. J. Hardman, C. Cui, H. W. Roesky, W. H. Fink and P. P. Power, Angew. Chem., Int. Ed., 2001, 40, 2172-2174; (d) R. J. Wright,
A. D. Phillips, T. L. Allen, W. H. Fink and P. P. Power, J. Am. Chem. Soc., 2003, 125, 1694-1695.

14 A. Y. Timoshkin, Coord. Chem. Rev., 2005, 249, 2094-2131.

15 (a) T. Chu, S. F. Vyboishchikov, B. M. Gabidullin and G. I. Nikonov, J. Am. Chem. Soc., 2017, 139, 8804-8807; (b) H. Zhu, J. Chai, V. Chandrasekhar, H. W. Roesky, J. Magull, D. Vidovic, H.-G. Schmidt, M. Noltemeyer, P. P. Power and W. A. Merrill, J. Am. Chem. Soc., 2004, 126, 9472-9473; (c) S. Schulz, L. Häming, R. Herbst-Irmer, H. W. Roesky and G. M. Sheldrick, Angew. Chem., Int. Ed. Engl., 1994, 33, 969-970.

16 C. Cui, S. Köpke, R. Herbst-Irmer, H. W. Roesky, M. Noltemeyer, H.-G. Schmidt and B. Wrackmeyer, J. Am. Chem. Soc., 2001, 123, 9091-9098.

17 H. Zhu, Z. Yang, J. Magull, H. W. Roesky, H.-G. Schmidt and M. Noltemeyer, Organometallics, 2005, 24, 6420-6425.

18 (a) C. Cui, H. W. Roesky, H.-G. Schmidt and M. Noltemeyer, Angew. Chem., Int. Ed., 2000, 39, 4531-4533; (b) N. J. Hardman and P. P. Power, Chem. Commun., 2001, 1184-1185.

19 D. B. Leznoff, G. Mund, K. C. Jantunen, P. H. Bhatia, A. J. Gabert and R. J. Batchelor, J. Nucl. Sci. Technol., 2002, 39, 406-409.

20 (a) R. J. Baker, C. Jones, M. Kloth and J. A. Platts, Angew. Chem., Int. Ed., 2003, 42, 2660-2663; (b) O. T. Beachley, S. H. L. Chao, M. R. Churchill and R. F. See, Organometallics, 1992, 11, 1486-1491.

21 E. W. Y. Wong, D. Dange, L. Fohlmeister, T. J. Hadlington and C. Jones, Aust. J. Chem., 2013, 66, 1144-1154.

22 T. J. Hadlington and C. Jones, Chem. Commun., 2014, 50, 2321-2323.

23 J. S. Silverman, C. J. Carmalt, A. H. Cowley, R. D. Culp, R. A. Jones and B. G. McBurnett, Inorg. Chem., 1999, 38, 296-300.

24 (a) N. H. Anderson, J. Xie, D. Ray, M. Zeller, L. Gagliardi and S. C. Bart, Nat. Chem., 2017, 9, 850; (b) L. A. Solola, A. V. Zabula, W. L. Dorfner, B. C. Manor, P. J. Carroll and E. J. Schelter, J. Am. Chem. Soc., 2016, 138, 6928-6931; (c) K. C. Mullane, A. J. Lewis, H. Yin, P. J. Carroll and E. J. Schelter, Inorg. Chem., 2014, 53, 9129-9139; (d) G. Bai, H. W. Roesky, M. Noltemeyer and H.-G. Schmidt, Organometallics, 2002, 21, 2789-2792. 